\title{
The Future of Forest Pathology in North America
}

\author{
Denita Hadziabdic ${ }^{*}$, Pierluigi Bonello ${ }^{2}$, Richard Hamelin ${ }^{3}$, Jennifer Juzwik ${ }^{4}$, \\ Bruce Moltzan ${ }^{5}$, David Rizzo ${ }^{6}$, Jane Stewart ${ }^{7}$ and Caterina Villari ${ }^{8}$ \\ ${ }^{1}$ Department of Entomology and Plant Pathology, University of Tennessee, Knoxville, Knoxville, TN, United States, \\ ${ }^{2}$ Department of Plant Pathology, The Ohio State University, Columbus, OH, United States, ${ }^{3}$ Department of Forest and \\ Conservation Sciences, The University of British Columbia, Vancouver, BC, Canada, ${ }^{4}$ Northern Research Station, U.S. \\ Department of Agriculture, Forest Service, St. Paul, MN, United States, ${ }^{5}$ Forest Health Protection, U.S. Department of \\ Agriculture, Forest Service, Washington, DC, United States, ${ }^{6}$ Department of Plant Pathology, University of California, Davis, \\ Davis, CA, United States, ${ }^{7}$ Department of Agricultural Biology, Colorado State University, Fort Collins, CO, United States, \\ ${ }^{8}$ Warnell School of Forestry and Natural Resources, University of Georgia, Athens, GA, United States
}

Keywords: forest pathology, changing climate, healthy forests, invasive pathogens, insect pests, chestnut blight, Dutch elm disease, sudden oak death

\section{HEALTHY FORESTS FOR A HEALTHY PLANET}

OPEN ACCESS

Edited by:

Ari Mikko Hietala,

Norwegian Institute of Bioeconomy

Research (NIBIO), Norway

Reviewed by:

Andrin Gross,

Snow and Landscape Research

(WSL), Switzerland

Paolo Gonthier,

University of Turin, Italy

*Correspondence: Denita Hadziabdic

dhadziab@utk.edu

Specialty section:

This article was submitted to

Pests, Pathogens and Invasions,

a section of the journal

Frontiers in Forests and Global

Change

Received: 08 July 2021 Accepted: 08 October 2021 Published: 18 November 2021

Citation:

Hadziabdic $D$, Bonello $P$, Hamelin $R$

Juzwik J, Moltzan B, Rizzo D,

Stewart J and Villari C (2021) The

Future of Forest Pathology in North

America.

Front. For. Glob. Change 4:737445

doi: 10.3389/ffgc. 2021.737445
Forests provide key ecosystem services globally, with economic values ranging from $\$ 125$ to $\$ 145$ trillion per year (Costanza et al., 2014). Forests are important not only for carbon sequestration goals and global biodiversity (Bonello et al., 2020a; Di Sacco et al., 2021; Palmer, 2021), but also for the economic (e.g., timber), environmental (e.g., water purification), and social (e.g., recreational activities) benefits (Trumbore et al., 2015) they provide (Bastin et al., 2019, 2020). Increasingly, forests are viewed as directly important to human health (Donovan et al., 2013); indeed, urban green environments are now considered essential in city planning (Nowak et al., 2006; Donovan and Butry, 2009; Donovan et al., 2013; Ideno et al., 2017).

The health of forests impacts their value and ability to deliver these ecosystem services. However, the definition of a healthy forest is actually quite complex and has long been debated (Raffa et al., 2009). In the absence of significant exogenous disturbances, forest ecosystems are ecologically dynamic, yet holistically stable and resilient. A healthy forest is not disease-free, but rather one that can self-perpetuate in a state of dynamic equilibrium, equivalent to a forest on its way to, or at, the climax state. A healthy forest, therefore, "encompasses a mosaic of successional patches representing all stages of the natural range of disturbance and recovery" (Trumbore et al., 2015). Indeed, a healthy forest supports pathogens and other disturbance agents that are essential for natural forest regeneration and nutrient cycling and, ultimately, increased resilience. Unfortunately, in the Anthropocene, forests have become increasingly threatened by humanmediated intensification of natural stressors, e.g., higher temperatures and lower water availability due to global warming, which make trees maladapted to their current habitats and thus more susceptible to insect pest and/or pathogen attacks (Sherwood et al., 2015).

\section{THE ANTHROPOCENE IS DISRUPTING THE NATURAL BALANCE}

Land-use changes and tree domestication aimed at large-scale plantations, often in monocultures, exacerbate susceptibility to insect pests and pathogens (Sturrock et al., 2011; Pautasso et al., 2015; Desprez-Loustau et al., 2016). With globalization proceeding unabated, natural, and planted forests are increasingly attacked by invasive alien insect pests and pathogens (Eriksson et al., 2019). Natural resources in Canada and the U.S. are becoming endangered at alarming rates because hosts that have not evolved resistance (i.e., naïve hosts) to such non-native insect pests and pathogens are inherently at risk of functional, if not actual, extinction (Pautasso et al., 2012, 2015; Santini et al., 2013; Trumbore et al., 2015; Albrich et al., 2020; Bonello et al., 2020a). While recently 
accelerating, this process has been ongoing since the onset of global commerce five centuries ago. In North America, some of the past non-native introductions, for example, Cryphonectria parasitica (chestnut blight) (Anagnostakis, 1987), Cronartium ribicola (white pine blister rust-WPBR) (Kinloch, 2003; Geils et al., 2010), and Ophiostoma ulmi and novo-ulmi (Dutch elm disease) (Gibbs, 1978), have caused irreversible changes to natural forest ecosystems. Examples of tree insect pests and pathogens that have changed forest ecosystems are not limited to the distant past: the last few decades have seen the appearance of damaging tree diseases such as sudden oak death (Rizzo and Garbelotto, 2003) and laurel wilt (Ploetz et al., 2017).

In some cases, invasive pathogens affect historically and culturally significant species, such as the 'ohi'a tree in Hawaii that is threatened by the fungal disease known as rapid 'ohi'a death [causal agents: Ceratocystis lukuohia and Ceratocystis huliohia (Mortenson et al., 2016; Barnes et al., 2018)]. These diseases can also have very broad ecosystem repercussions and affect species that are not directly attacked by the pathogens, but depend on the services provided by trees for their survival. For example, landscape-level mortality caused by the oak wilt agent: [causal agent: Bretziella fagacearum (Juzwik et al., 2011)], in both rural and urban forests in the U.S., negatively impacts endangered species that depend on oaks, such as the golden-cheeked warbler in Texas (Appel and Camilli, 2010). Similarly, WPBR threatens high-elevation pines such as whitebark pine (Pinus albicaulis), a keystone species that provides ecosystem services such as food for grizzly bears, erosion prevention, and microhabitat provisioning for plants and animals (Keane and Arno, 1993; Tomback and Achuff, 2010). By severely damaging the selfperpetuating properties of healthy forests, newly introduced insect pests and pathogens reduce the ecological resilience of our forest landscapes (Pautasso et al., 2015; Abrams et al., 2021).

\section{CLIMATE CHANGE IS THE CHALLENGE OF THE FUTURE}

Climate change is having a compounding impact on forest health (Kolb et al., 2016; Ramsfield et al., 2016) because it makes trees maladapted to their current environments. Yet, little is known of the potential outcomes of a changing climate on forest health (Seidl et al., 2017). More prolonged and extreme periods of drought, or increasing rainfall, will likely increase the frequency of abiotic stress events making tree hosts more vulnerable to both insect pest and pathogen attack. Some of the new and future climatic conditions will also provide novel niches for nonnative invasive insect pests and pathogens as well as expanding the niches of native ones. For example, Dothistroma pini (Dothistroma needle blight), Nothophaeocryptopus gaeumannii (Swiss needle cast), and Diplodia sapinea (Diplodia tip blight and canker) have increased in frequency and intensity, creating large-scale defoliation and mortality that is driven by new climatic conditions, whether caused by more rainfall or drought conditions depending on areas where each of these occur (Woods et al., 2005; Stone et al., 2008; Brodde et al., 2019). Moreover, climate change also causes shifts in forest tree species composition. Well-known examples include changes from large trees in conifer-dominated European mountain landscapes to those dominated by smaller, mainly broadleaved trees (Albrich et al., 2020), which fundamentally alters the underlying forest health framework. Climate shifts are also expected to result in novel ecosystems, driven by migration and species distribution expansion of both hosts and pathogens (Pautasso et al., 2015). Ultimately, this will likely lead to further unforeseen forest health issues, spanning across wider geographical regions and affecting ecosystem services across continents.

\section{FOREST PATHOLOGISTS ARE NEEDED TO FIND SOLUTIONS}

The combined impact of invasive alien insect pests and pathogens and climate change can create enormous economic and environmental costs to our society, in the range of \$4.3-20.2 trillion per year in ecosystem service losses (Costanza et al., 2014). Mitigating those losses is one of the most pressing challenges to ensure future healthy forests and continued provision of services. Forest health research can lead to innovative solutions and is central to both short- and long-term approaches. Predicting the outcome of host-pathogen-pest interactions in a changing climate will be a very important research avenue for future forest health (Desprez-Loustau et al., 2016). Highly trained forest pathologists are needed to mitigate this crisis. Forest tree pathogens attack long-lived organisms with highly differentiated woody tissue types, which requires a specialized understanding of tree-microbe-environment interactions. This skill set differs greatly from that required for agricultural crop plants, which are primarily annual, herbaceous, and confined to highly simplified agroecosystems. Forest pathology thus represents the necessary fusion of forest ecology and plant pathology required to understand the complexities of forest community structure and composition, pathogen-based biology, biogeography, forestry, genetics, and genomics within the context of host defense and resistance. By necessity, all of these diverse scientific domains pose challenges for the non-specialist, who is not adequately armed with the integrated knowledge necessary to formulate cogent management strategies.

The field of forest pathology is not new: it has developed over 130 years, stimulated by the severe impact of nonnative, pathogen-caused epidemics during the first half of the twentieth century and with the purpose of preventing or controlling such events in the future (Boyce, 1961). Since the early 1980s, forest pathology positions in academia and the federal government in North America have undergone a steep decline, despite the significant increase in emerging pest issues (Martyn, 2009; Santini et al., 2013; Bonello et al., 2020b). Lack of trained personnel has occurred in tandem with reductions in organizationally visible forest pathology programs across forestry and plant pathology departments throughout the U.S. and Canada. The latter is a result of smaller departments being combined into larger units/divisions or simply being dissolved. This has resulted in the further erosion of forest pathology training (including faculty positions) in higher education, often 
with forest pathology as a subject being relegated to a singular course or being combined into a forest protection/forest health course focused on diseases, insect pests, and/or fire.

The number of classically trained forest pathology faculty positions at U.S. universities has declined from over 40 positions in the 1980 s to 22 positions in 2021. This includes 14 universities in which a forest pathologist faculty position was not replaced following retirement. In the federal government sector, there has also been a steep reduction in the total number of USDAFS-Research and Development research scientist positions since 1985. Between 1985 and 2007, the number of all research scientists decreased by $44 \%$ (from 985 to 547) (USDA FS, 2007). The proportional change in position numbers, however, did vary by research series classification. Currently, the series with larger numbers of FS researchers include Research Ecologist, Research Forester, and Research Social Scientist. In comparison, there are currently nine Research Plant Pathologists employed (estimated $2.2 \%$ of the research scientist cadre) (NFC Insight data, USDA OCIO Enterprise Analytics Team). Between 1985 and 2007, the proportion of scientists in this series per total research scientists decreased from 5.1 to $2.9 \%$ (USDA FS, 2007). The USDA FS also employs Plant Pathologists (non-research positions) with responsibilities for detection and monitoring, oversight of federally funded disease suppression programs, and technical assistance. These plant pathologists (39 in 2021 per NFC Insight data, USDA OCIO Enterprise Analytics Team) may be considered the "first responders" while research plant pathologists are often the initial investigators of new and emerging tree disease.

\section{SUCCESS STORIES IN FOREST PATHOLOGY}

Forest-pathology-based research has generated some considerable successes in tree disease management. One important case is represented by Heterobasidion root disease (HRD), caused by the Heterobasidion annosum species complex. HRD is found throughout coniferous forests of the Northern Hemisphere (Garbelotto and Gonthier, 2013). Heterobasidion irregulare, one of the species in this complex, is considered a native species in North America and it has a very low impact in unmanaged or extensively managed forests but causes high mortality in intensively managed pine plantations (Otrosina and Garbelotto, 2010). An innovative solution was developed, based on the pathogen infection cycle (which occurs via freshly cut stumps with additional spread through root contacts) by treating stumps with borate compounds (e.g., disodium octaborate tetrahydrate or DOT) or by inoculating the stumps with saprobic wood decay fungi such as Phlebiopsis gigantea that outcompete the pathogen. These strategies are considered "among the most effective and sustainable in forestry" and are commercially available around the world, preventing the death of millions of trees (Garbelotto and Gonthier, 2013).

Tree breeding for disease resistance is another successful avenue for controlling tree diseases. Fusiform rust (Cronartium quercuum f. sp. fusiforme) is a very damaging pathogen that attacks the stems and branches of pines, causing high levels of mortality. Breeding for disease resistance has made it possible to control fusiform rust to maintain low disease levels in loblolly and slash pine plantations in the southern U.S. (Schmidt, 2003). Breeding for disease resistance can also help protect endangered tree species. Several white pine species, including high elevation white pines, have now been bred for resistance to $\mathrm{WPBR}$, making it possible to restore white pines in areas where these pines were previously endangered (Sniezko et al., 2014). Breeding and developing resistant PortOrford-cedar (POC) for resistance to the exotic root pathogen Phytophthora lateralis (Zobel et al., 1985) is another success story (Sniezko et al., 2012). Planting resistant POC and developing operational use of multiple disease management practices have been credited with the recent downgrade of POC status from "vulnerable" to "near threatened" by the IUNC (Pike et al., 2021).

Pathogen identification and detection have revolutionized how we diagnose tree diseases (Stewart et al., 2018). Plant health clinics now routinely use DNA-based methods (Martin et al., 2009; Wu et al., 2011; Lamarche et al., 2015; Yang and Juzwik, 2017; Oren et al., 2018; Parra et al., 2020; Rizzo et al., 2021; Stackhouse et al., 2021) that provide rapid and accurate diagnostics. Regulatory agencies have adopted the tools developed by forest pathologists for their day-to-day testing for invasive species. This has been instrumental in preventing the spread and tracking sources of pathogens such as Phytophthora ramorum (sudden oak death) (Grünwald et al., 2019). PCR tests targeting this pathogen have now been used millions of times around the world to provide rapid and reliable molecular identification and help contain this pathogen to western states and provinces of North America (Martin et al., 2009).

Ultimately, it is the integration of multiple approaches that offers the best long-term solutions. This is the case with oak wilt, initially recognized as a mysterious rapid wilting of black oaks (Quercus velutina) that was discovered in the early 1940s (Henry 1944), shortly after the discovery of chestnut blight and Dutch elm disease in North America. The fungus B. fagacearum spreads above-ground by insect vectors and below-ground through naturally grafted root systems and is known to occur only in the eastern U.S., where it is arguably considered non-native (Juzwik et al., 2008). Control tools and management approaches developed by forest pathologists over the past 75 years and implemented in both urban and rural forests have resulted in effective multi-pronged disease management. Above-ground pathogen transmission by sap beetles (Coleoptera: Nitidulidae) is minimized by timely removal of wilted red oaks, avoidance of oak wounding during high-risk season(s), and restricting movement of firewood and logs with bark from oak wilt-affected areas. Below-ground transmission is stopped by mechanical disruption of common or grafted root systems between diseased and nearby healthy oaks. These selected success stories demonstrate the need for increased research capacity for multidisciplinary approaches that range from basic research for knowledge acquisition to applied research to find solutions. 


\section{THE NEED FOR FOREST PATHOLOGISTS IN THE FUTURE}

Forest pathology researchers and practitioners are our first line of defense, one that is constantly under pressure from a variety of stakeholders facing new and re-emerging forest health issues. Although there are a number of success stories related to mitigating forest diseases, new, unknown, and emerging pest issues are on the rise (Santini et al., 2013). The challenge of predicting outbreaks under future climates and the increasing global movement of invasive pathogens will require novel skills. The need for a traditional "forest specialist" worked well in the past because there were enough "unknown" disease etiologies to investigate and sustain the career of several forest pathologists to tackle a single disease system for decades. However, future generations of forest pathologists will require even more multidisciplinary training and approaches. They will need to acquire multidisciplinary knowledge to better characterize diverse pathosystems (Martyn, 2009). Furthermore, it is critical that resource opportunities sufficient to support the clear needs identified here be strategic, focused, and applied across the continuum of basic to applied research and solution implementation. An expanding cadre of research forest pathologists with the modern training necessary to tackle these problems is urgently needed.

The current forest health crisis brought about by climate change and globalization creates the need and opportunity to train the upcoming generation of forest pathologists. For example, multidisciplinary research consortia are increasingly necessary to tackle the societal grand challenges that forest decline syndromes represent. Such consortia must include

\section{REFERENCES}

Abrams, J., Greiner, M., Schultz, C., Evans, A., and Huber-Stearns, H. (2021). Can forest managers plan for resilient landscapes? Lessons from the United States national forest plan revision process. Environ. Manage. 67, 574-588. doi: 10.1007/s00267-021-01451-4

Albrich, K., Rammer, W., and Seidl, R. (2020). Climate change causes critical transitions and irreversible alterations of mountain forests. Glob. Chang. Biol. 26, 4013-4027. doi: 10.1111/gcb.15118

Anagnostakis, S. L. (1987). Chestnut Blight: the classical problem of an introduced pathogen. Mycologia 79, 23-37. doi: 10.2307/3807741

Appel, D. N., and Camilli, K. S. (2010). "Assessment of oak wilt threat to habitat of the golden-cheeked warbler, an endangered species, in central Texas," in Advances in threat assessment and their application to forest and rangeland management. Gen. Tech. Rep. PNW-GTR-802, eds J. M. Pye, H. M. Rauscher, Y. Sands, D. C. Lee, and J. S. Beatty, (Portland, OR: US Department of Agriculture, Forest Service, Pacific Northwest and Southern Research Stations), 61-71.

Barnes, I., Fourie, A., Wingfield, M. J., Harrington, T., McNew, D., Sugiyama, L., et al. (2018). New Ceratocystis species associated with rapid death of Metrosideros polymorpha in Hawai'i. Persoonia 40, 154-181. doi: $10.3767 /$ persoonia.2018.40.07

Bastin, J.-F., Finegold, Y., Garcia, C., Mollicone, D., Rezende, M., Routh, D., et al. (2019). The global tree restoration potential. Science 365, 76-79. doi: $10.1126 /$ science.aax0848

Bastin, J.-F., Finegold, Y., Garcia, C., Mollicone, D., Rezende, M., Routh, D., et al. (2020). Erratum for the Report: "The global tree restoration forest pathologists, forest entomologists, forest ecologists, silviculturists, traditional forest geneticists, modelers, remote sensing specialists, as well as experts in artificial intelligence, microbial ecology, and novel genomics approaches such as CRISPR-Cas9, to name a few. This will require constant inputs and multiple resource providers and careful and intentional strategic planning to achieve defined forest health objectives. The past and current generations of forest pathologists have demonstrated the value of their work by providing innovative solutions to forest health challenges. The next generation of forest pathologists will have access to an extraordinary toolbox ranging from classical to cutting-edge tools to address and provide solutions to current and future forest health crises. They should be at the forefront of the fight against invasive tree pest and pathogen invasions in the era of climate change.

\section{AUTHOR CONTRIBUTIONS}

All authors listed have made a substantial, direct and intellectual contribution to the work, and approved it for publication.

\section{FUNDING}

Funding and salaries for this project were provided by state and federal funds appropriated to the University of Tennessee Institute of Agriculture, University of Tennessee; the Ohio Agricultural Research and Development Center, The Ohio State University; The University of British Columbia; United States Department of Agriculture-Forest Service; University of California; Colorado State University; and the D. B. Warnell School of Forestry and Natural Resources, University of Georgia.

potential" by J.-F. Bastin, Y. Finegold, C. Garcia, D. Mollicone, M. Rezende, D. Routh, C. M. Zohner, T. W. Crowther and for the Technical Response "Response to Comments on 'The global tree restoration potential"' by J.-F. Bastin, Y. Finegold, C. Garcia, N. Gellie, A. Lowe, D. Mollicone, M. Rezende, D. Routh, M. Sacande, B. Sparrow, C. M. Zohner, T. W. Crowther. Science 368, eabc8905. doi: 10.1126/science.ab c8905

Bonello, P., Campbell, F. T., Cipollini, D., Conrad, A. O., Farinas, C., Gandhi, K. J. K., et al. (2020a). Invasive tree pests devastate ecosystems - a proposed new response framework. Front For Glob Change 3, 2. doi: 10.3389/ffgc.2020. 00002

Bonello, P., Hadziabdic, D., Rizzo, D., Tomimatsu, G., and Beattie, G. (2020b). Bolstering forest pathology to ensure a robust forest health community for the future. Phytopathol. News 54.

Boyce, J. S. (1961). Forest Pathology, 3rd Edn. New York, NY: McGraw-Hill.

Brodde, L., Adamson, K., Julio Camarero, J., Castaño, C., Drenkhan, R., Lehtijärvi, A., et al. (2019). Diplodia tip blight on its way to the North: drivers of disease emergence in Northern Europe. Front. Plant Sci. 9:1818. doi: 10.3389/fpls.2018.01818

Costanza, R., de Groot, R., Sutton, P., van der Ploeg, S., Anderson, S., I, K, Kubiszewski I, et al. (2014). Changes in the global value of ecosystem services. Glob. Environ. Change 26, 152-158. doi: 10.1016/j.gloenvcha.2014.04.002

Desprez-Loustau, M.-L., Aguayo, J., Dutech, C., Hayden, K. J., Husson, C., Jakushkin, B., et al. (2016). An evolutionary ecology perspective to address forest pathology challenges of today and tomorrow. Ann. For. Sci. 73, 45-67. doi: 10.1007/s13595-015-0487-4 
Di Sacco, A., Hardwick, K. A., Blakesley, D., Brancalion, P. H. S., Breman, E., Cecilio Rebola, L., et al. (2021). Ten golden rules for reforestation to optimize carbon sequestration, biodiversity recovery and livelihood benefits. Glob. Chang. Biol. 27, 1328-1348. doi: 10.1111/gcb.15498

Donovan, G. H., and Butry, D. T. (2009). The value of shade: estimating the effect of urban trees on summertime electricity use. Energy Build. 41, 662-668. doi: 10.1016/j.enbuild.2009.01.002

Donovan, G. H., Butry, D. T., Michael, Y. L., Prestemon, J. P., Liebhold, A. M., Gatziolis, D., et al. (2013). The relationship between trees and human health: evidence from the spread of the emerald ash borer. Amer. J. Prevent. Med. 44, 139-145. doi: 10.1016/j.amepre.2012.09.066

Eriksson, L., Boberg, J., Cech, T. L., Corcobado, T., Desprez-Loustau, M.-L., Hietala, A. M., et al. (2019). Invasive forest pathogens in Europe: cross-country variation in public awareness but consistency in policy acceptability. Ambio 48, 1-12. doi: 10.1007/s13280-018-1046-7

Garbelotto, M., and Gonthier, P. (2013). Biology, epidemiology, and control of Heterobasidion species worldwide. Annu. Rev. Phytopathol. 51, 39-59. doi: 10.1146/annurev-phyto-082712-102225

Geils, B. W., Hummer, K. E., and Hunt, R. S. (2010). White pines, Ribes, and blister rust: a review and synthesis. For. Pathol. 40, 147-185. doi: 10.1111/j.1439-0329.2010.00654.x

Gibbs, J. N. (1978). Intercontinental epidemiology of Dutch Elm disease. Annu. Rev. Phytopathol. 16, 287-307. doi: 10.1146/annurev.py.16.090178.001443

Grünwald, N. J., LeBoldus, J. M., and Hamelin, R. C. (2019). Ecology and evolution of the sudden oak death pathogen Phytophthora ramorum. Annu. Rev. Phytopathol. 57, 301-321. doi: 10.1146/annurev-phyto-082718-100117

Ideno, Y., Hayashi, K., Abe, Y., Ueda, K., Iso, H., Noda, M., et al. (2017). Blood pressure-lowering effect of Shinrin-yoku (Forest bathing): a systematic review and meta-analysis. BMC Complement. Altern. Med. 17, 409. doi: 10.1186/s12906-017-1912-z

Juzwik, J., Appel, D., MacDonald, W., and Burks, S. (2011). Challenges and successes in managing Oak Wilt in the United States. Plant Dis. 95, 888-900. doi: 10.1094/PDIS-12-10-0944

Juzwik, J., Harrington, T. C., MacDonald, W. L., and Appel, D. N. (2008). The origin of Ceratocystis fagacearum, the oak wilt fungus. Annu. Rev. Phytopathol. 46, 13-26. doi: 10.1146/annurev.phyto.45.062806.094406

Keane, R. E., and Arno, S. F. (1993). Rapid decline of whitebark pine in western Montana: evidence from 20-year remeasurements. Western J. Appl. Forest 8, 44-47. doi: 10.1093/wjaf/8.2.44

Kinloch, B. B. (2003). White pine blister rust in North America: past and prognosis. Phytopathology 93, 1044-1047. doi: 10.1094/PHYTO.2003.93.8.1044

Kolb, T. E., Fettig, C. J., Ayres, M. P., Bentz, B. J., Hicke, J. A., Mathiasen, R., et al. (2016). Observed and anticipated impacts of drought on forest insects and diseases in the United States. For. Ecol. Manage. 380, 321-334. doi: 10.1016/j.foreco.2016.04.051

Lamarche, J., Potvin, A., Pelletier, G., Stewart, D., Feau, N., Alayon, D. I. O., et al. (2015). Molecular detection of 10 of the most unwanted alien forest pathogens in Canada using real-time PCR. PLOS ONE 10, e0134265. doi: 10.1371/journal.pone.0134265

Martin, F. N., Coffey, M. D., Zeller, K., Hamelin, R. C., Tooley, P., Garbelotto, M., et al. (2009). Evaluation of molecular markers for Phytophthora ramorum detection and identification: testing for specificity using a standardized library of isolates. Phytopathology 99, 390-403. doi: 10.1094/PHYTO-99-4-0390

Martyn, R. D. (2009). Where will the next Norman Borlaug come from? A U.S. perspective of plant pathology education and research. Plant Protect. Sci. 45, 125-139. doi: 10.17221/22/2009-PPS

Mortenson, L. A., Flint Hughes, R., Friday, J. B., Keith, L. M., Barbosa, J. M., Friday, N. J., et al. (2016). Assessing spatial distribution, stand impacts and rate of Ceratocystis fimbriata induced 'ohi'a (Metrosideros polymorpha) mortality in a tropical wet forest, Hawai'i Island, USA. For. Ecol. Manage. 377, 83-92. doi: 10.1016/j.foreco.2016.06.026

Nowak, D. J., Crane, D. E., and Stevens, J. C. (2006). Air pollution removal by urban trees and shrubs in the United States. Urb. Forest. Urb. Green. 4, 115-123. doi: 10.1016/j.ufug.2006.01.007

Oren, E., Klingeman, W., Gazis, R., Moulton, J., Lambdin, P., Coggeshall, M., et al. (2018). A novel molecular toolkit for rapid detection of the pathogen and primary vector of thousand cankers disease. PLOS ONE 13, e0185087. doi: 10.1371/journal.pone.0185087

Otrosina, W. J., and Garbelotto, M. (2010). Heterobasidion occidentale sp nov and Heterobasidion irregulare nom. nov.: a disposition of North
American Heterobasidion biological species. Fung Biol. 114, 16-25. doi: 10.1016/j.mycres.2009.09.001

Palmer, L. (2021). How trees and forests reduce risks from climate change. Nat. Clim. Chang. 11, 374-377. doi: 10.1038/s41558-021-01041-6

Parra, P. P., Dantes, W., Sandford, A., de la Torre, C., Pérez, J., Hadziabdic, D., et al. (2020). Rapid detection of the laurel wilt pathogen in sapwood of Lauraceae hosts. Plant Health Prog. 21, 356-364. doi: 10.1094/PHP-06-20-0049-RS

Pautasso, M., Döring, T. F., Garbelotto, M., Pellis, L., and Jeger, M. J. (2012). Impacts of climate change on plant diseases-opinions and trends. Eur. J. Plant Pathol. 133, 295-313. doi: 10.1007/s10658-012-9936-1

Pautasso, M., Schlegel, M., and Holdenrieder, O. (2015). Forest health in a changing world. Microb. Ecol. 69, 826-842. doi: 10.1007/s00248-014-0545-8

Pike, C. C., Koch, J., and Nelson, C. D. (2021). Breeding for resistance to tree pests: successes, challenges, and a guide to the future. J. Forest. 119, 96-105. doi: 10.1093/jofore/fvaa049

Ploetz, R. C., Kendra, P. E., Choudhury, R. A., Rollins, J. A., Campbell, A., Garrett, K., et al. (2017). Laurel Wilt in natural and agricultural ecosystems: understanding the drivers and scales of complex pathosystems. Forests 8, 48. doi: 10.3390/f8020048

Raffa, K. F., Aukema, B., Bentz, B. J., Carroll, A., Erbilgin, N., Herms, D. A., et al. (2009). A literal use of "forest health" safeguards against misuse and misapplication. J. Forest. 107, 276-277. Available online at: https://www.fs.usda. gov/treesearch/pubs/19615

Ramsfield, T., Bentz, B., Faccoli, M., Jactel, H., and Brockerhoff, E. (2016). Forest health in a changing world: effects of globalization and climate change on forest insect and pathogen impacts. Forestry 89, 245-252. doi: 10.1093/forestry/cpw018

Rizzo, D., and Garbelotto, M. (2003). Sudden oak death: endangering California and Oregon forest ecosystems. Front. Ecol. Environ. 1, 197-204. doi: 10.1890/ 1540-9295(2003)001[0197:SODECA]2.0.CO;2

Rizzo, D., Moricca, S., Bracalini, M., Benigno, A., Bernardo, U., Luchi, N., et al (2021). Rapid detection of Pityophthorus juglandis (Blackman) (Coleoptera, Curculionidae) with the Loop-Mediated Isothermal Amplification (LAMP) method. Plants 10, 1048. doi: 10.3390/plants10061048

Santini, A., Ghelardini, L., De Pace, C., Desprez-Loustau, M. L., Capretti, P., Chandelier, A., et al. (2013). Biogeographical patterns and determinants of invasion by forest pathogens in Europe. New Phytol. 197, 238-250. doi: 10.1111/j.1469-8137.2012.04364.x

Schmidt, R. A. (2003). Fusiform rust of southern pines: a major success for forest disease management. Phytopathology 93, 1048-1051. doi: 10.1094/PHYTO.2003.93.8.1048

Seidl, R., Thom, D., Kautz, M., Martin-Benito, D., Peltoniemi, M., Vacchiano, G., et al. (2017). Forest disturbances under climate change. Nat. Clim. Chang. 7, 395-402. doi: 10.1038/nclimate3303

Sherwood, P., Villari, C., Capretti, P., and Bonello, P. (2015). Mechanisms of induced susceptibility to Diplodia tip blight in drought-stressed Austrian pine. Tree Physiol. 35, 549-562. doi: 10.1093/treephys/tpv026

Sniezko, R., Hamlin, J., and Hansen, E. (2012). "Operational program to develop Phytophthora lateralis-resistant populations of Port-Orford-cedar (Chamaecyparis lawsoniana)," in Proceedings of the Fourth International Workshop on the Genetics of Host-Parasite Interactions in Forestry: Disease and Insect Resistance in Forest Trees. Gen. Tech. Rep. PSW-GTR-240, Vol. 240 (Albany, CA: Pacific Southwest Research Station, Forest Service, US Department of Agriculture), 65-79.

Sniezko, R. A., Smith, J., Liu, J.-J., and Hamelin, R. C. (2014). Genetic resistance to Fusiform rust in southern pines and white pine blister rust in white pines - a contrasting tale of two rust pathosystems - current status and future prospects. Forests 5, 2050-2083. doi: 10.3390/f5092050

Stackhouse, T., Boggess, S., Hadziabdic, D., Trigiano, R. N., Ginzel, M., and Klingeman, W. (2021). Conventional gel electrophoresis and TaqMan probes enable rapid confirmation of Thousand Cankers Disease from diagnostic samples. Plant Dis. doi: 10.1094/PDIS-10-20-2258-RE. [Epub ahead of print].

Stewart, J. E., Kim, M.-S., and Klopfenstein, N. B. (2018). Molecular genetic approaches toward understanding forest-associated fungi and their interactive roles within forest ecosystems. Curr. Forest. Rep. 4, 72-84. doi: 10.1007/s40725-018-0076-5

Stone, J. K., Coop, L. B., and Manter, D. K. (2008). Predicting effects of climate change on Swiss needle cast disease severity in Pacific Northwest forests. Canad. J. Plant Pathol.30, 169-176. doi: 10.1080/07060661.2008.10 540533 
Sturrock, R. N., Frankel, S. J., Brown, A. V., Hennon, P. E., Kliejunas, J. T., Lewis, K. J., et al. (2011). Climate change and forest diseases. Plant Pathol. 60, 133-149. doi: 10.1111/j.1365-3059.2010.02406.x

Tomback, D. F., and Achuff, P. (2010). Blister rust and western forest biodiversity: ecology, values and outlook for white pines. For. Pathol. 40, 186-225. doi: $10.1111 / j .1439-0329.2010 .00655 . x$

Trumbore, S., Brando, P., and Hartmann, H. (2015). Forest health and global change. Science 349, 814-818. doi: 10.1126/science.aac6759

USDA Forest Service. (2007). USDA Forest Service Research \& Development 2006 highlights. Report No. FS-890. USDA Forest Service. p 58. Available online at: https://www.frames.gov/catalog/8414

Woods, A., Coates, K. D., and Hamann, A. (2005). Is an unprecedented Dothistroma needle blight epidemic related to climate change? Bioscience 55, 761-769. doi: 10.1641/0006-3568(2005)055[0761:IAUDNB] 2.0.CO;2

Wu, C. P., Chen, G. Y., Li, B., Su, H., An, Y. L., Zhen, S. Z., et al. (2011). Rapid and accurate detection of Ceratocystis fagacearum from stained wood and soil by nested and real-time PCR. For. Pathol. 41, 15-21. doi: $10.1111 /$ j.1439-0329.2009.00628.x

Yang, A., and Juzwik, J. (2017). Use of nested and real-time PCR for the detection of Ceratocystis fagacearum in the sapwood of diseased oak species in Minnesota. Plant Dis. 101, 480-486. doi: 10.1094/PDIS-07-160990-RE
Zobel, D. B., Roth, L. F., and Hawk, G. M. (1985). Ecology, Pathology, and Management of Port-Orford-cedar (Chamaecyparis lawsoniana). General Technical Report PNW- 184, Vol. 184. US Department of Agriculture, Forest Service, Pacific Northwest Forest and Range Experiment Station, p. 161.

Conflict of Interest: The authors declare that the research was conducted in the absence of any commercial or financial relationships that could be construed as a potential conflict of interest.

Publisher's Note: All claims expressed in this article are solely those of the authors and do not necessarily represent those of their affiliated organizations, or those of the publisher, the editors and the reviewers. Any product that may be evaluated in this article, or claim that may be made by its manufacturer, is not guaranteed or endorsed by the publisher.

Copyright (c) 2021 Hadziabdic, Bonello, Hamelin, Juzwik, Moltzan, Rizzo, Stewart and Villari. This is an open-access article distributed under the terms of the Creative Commons Attribution License (CC BY). The use, distribution or reproduction in other forums is permitted, provided the original author(s) and the copyright owner(s) are credited and that the original publication in this journal is cited, in accordance with accepted academic practice. No use, distribution or reproduction is permitted which does not comply with these terms. 